\title{
A study on livelihood activities followed by the male rural youths in flood affected Dhemaji district of Assam state of India
}

\author{
Madhu Kakoty ${ }^{1}$, Utpal Barman ${ }^{2 *}$ and Shyamolima Saikia ${ }^{2}$ \\ ${ }^{1}$ Assam State Seed Certification Agency, Government of Assam, Jorhat-785001 (Assam), INDIA \\ ${ }^{2}$ Department of Extension Education, College of Agriculture, Assam Agricultural University, Jorhat-785013 \\ (Assam), INDIA \\ *Corresponding author. E-mail: barman.utpal@gmail.com
}

Received: February 10, 2016; Revised received: August 30, 2017; Accepted: January 17, 2018

\begin{abstract}
The study was conducted at flood affected Dhemaji district of Assam where the flood is a major concern for the livelihood of rural male youth. The paper focused on existing livelihood activities opted by of rural male youths, their reason for choosing the activities and problems encountered in doing it. To date, no study has looked specifically at all the three aspects. The present study together investigated all the three elements. The study selected 200 rural male youths from the district as respondents following multistage random sampling. The survey found the mean age of the respondents as 28.83 years. The study found that the respondents opted 17 types of livelihood activities. Most $(25.50 \%)$ of the interviewees chose sali rice cultivation, and they $(100.00 \%)$ cited the availability of suitable land as a reason. Under vegetable cultivation, $96.07 \%$ respondents mentioned scope for round the year production and income generation as reasons. The respondents opted piggery $(100.00 \%)$, poultry $(100.00 \%)$, weaving $(100.00 \%)$, dairy $(92.85 \%)$, goatery $(91.66 \%)$ and fishery $(90.00 \%)$ mentioned high market demand as a reason. Regarding the problem, all respondents $(100.00 \%)$ opting sali rice cultivation and vegetable cultivation reported flood, flood-induced sand and insufficient irrigation as problems. The high price of improved livestock breed was an issue for respondents (100.00\%) opting dairy, poultry, and piggery. In fishery, $80.00 \%$ respondents mentioned nonavailability of quality fingerlings as a problem. The paper urges the policy makers, researchers and development organisations for utilising the findings to select appropriate interventions for providing livelihood security to male rural youths of Dhemaji district of Assam State, India.
\end{abstract}

Keywords: Dhemaji, Flood affected area, Livelihood, activities, Male rural youths

\section{INTRODUCTION}

Rural areas are the most marginalised and characterised by poverty (Alemu, 2012). Hence, IFAD ,2001( as cited in Umunnakwe et al., 2014 ) reported that poverty predominantly remains a rural phenomenon in most of the developing country.There has been an increase in unemployment, creating poverty like situations for many. Livelihoods of rural people are agriculture-centric. The per capita land available to each family is decreasing with the increase of household members. So supporting the families through agriculture alone is becoming difficult. Since the land available to each family has remained the same and the number of family members has grown, supporting all of them through agriculture alone is becoming difficult. Rural people are now migrating to towns and cities in search of jobs. However, these were also not always available partly because of lacking the qualifications and skills ('Livelihood-Rural Indian-Citizens', 2012). Rural youths are more prone to migration since they are more concern for their fu- ture livelihood security. The World Bank (2007) argued that young people be $40.00 \%$ more likely to migrate than older people from rural to urban areas. India by and large is an agriculture centric country. Small and marginal holdings together, constitute 85.00 $\%$ regarding the number of operational holdings and $44.00 \%$ of the operated area in the country as informed by Bakshi (2013) in an interview given to Dhandeo (2013). 'In future, Indian agriculture will be dominated by marginal and small holdings, on which application of new agricultural technologies would become more challenging' (Rao, 1989 as cited in 'Introduction' (n.d.). According to him, opportunities were also open to those farmers regarding the increasing scope of human labour intensive enterprises. It is because of increasing consumption of high-value commodities which will increase such demand. Within the agricultural sector, the high-value segment is expected to contribute more to the well being of the small holders, as its require more labour and generate higher returns than cereals (Joshi et al., 2006). According to Census of India $(2011)^{\mathrm{a}}$, youth constituted $28.00 \%$ of 
total population, and about 46.9 million of them(aged 15-24 years) were unemployed as cited by Jha,(2014). Although the dependency ratio in India is declining, the youth unemployment remains high (Sanghi and Srija, 2014). The youth is the most dynamic and potential segment of the population of any country. According to United Nations youths are a major human resource for development and key agents for social change, economic growth and technological innovation ('Youth Participation', n.d.). Waldie (2014) argued that rural youths should get the opportunity to build their livelihoods on their terms. He stated that understanding the livelihood strategies of youth should be the starting point "for developing policies and programmes that take into account the ambitions and initiatives of the young". In developing countries, agriculture is the primary source of employment for a significant portion of the population (Vergas Lundius and Lanly, 2007). In rural areas, youths mostly depended on agriculture for subsistence (Umunnakwe et al., 2014). National Sample Survey Organisation (2005) reported that an estimated $27.00 \%$ of farmers did not like farming because it was not profitable. In all, $40.00 \%$ felt that, given a choice, they would take up some other career. According to Swaminathan (2001), about 2,035 farmers are losing 'Main Cultivator' status every day in India. Sharma and Bhaduri (2009) claimed that shortly Indian agriculture would face the challenges to retain the youth in the agriculture.In recent years, researchers have become increasingly interested in livelihood activities of rural young people.

This paper focuses on livelihood activities of rural youths of Dhemaji district of Assam. It is one of the backwards, and worst floods affected districts of India. It ranked 60 among backwards districts of India (Planning Commission, 2003).The district had 47.29\% tribal population, and $92.16 \%$ population lives in rural areas (Census of India, 2011 ${ }^{\mathrm{b}}$ ). About $70.00 \%$ area of the district is affected by the flood. Flood accompanied by erosion and sand deposition caused maximum damage to the agricultural sector of the area ('Economy of Dhemaji District', n.d.). Das (2012) mentioned that the district virtually transformed into a desert due to floodinduced sand deposition in paddy land. He reported that in nearly $83.00 \%$ of the total paddy areas encountered with the problem of flood-induced sand deposition. He found that sand deposition has been decreasing agricultural income which had triggered large-scale out-migration of rural youths. In a report of Government of India (2010) argued that the proportion of outmigrants be significantly higher in Dhemaji compared to the rest of the country. Chetia (2014) claimed that at present it is a common practice of rural youths of Dhemaji for out-migration to other states in search of livelihood.

If rural youths are provided with proper opportunities to build their livelihood on their terms, they can im- prove their living standard. Krantz (2001) mentioned that several international development agencies are now following a 'livelihoods approach' where three basic features, are common. The first it is that the approach focuses on the livelihoods of the poor. Secondly, it rejects the usual common sectoral entry point (e.g. Agriculture, water, or health) and instead begins with an analysis of people's current livelihood systems to identify an appropriate intervention. At last, it emphasises on involving people in the identification and implementation of activities if applicable. Bennell (2007) argued that boys spend more time in income generating activities than girls. Therefore, they are likely to be supported separately. Understanding the existing livelihood pattern of rural male youths, reasons for adopting the activities and problems encountered by them in pursuing the activities will help to identify the proper intervention for them. To date, scant attention has been paid to investigate these three aspects in a single study to get a clear picture of rural male- youths of Dhemaji district. The significance of the paper is that examines all these three issues combined which will contribute to select appropriate interventions for subsistence. If the rural young men receive proper facilities for gainful employment based on their choice, they will continue livelihood in their villages. So understanding the existing livelihood pattern of rural youth helps us to provide gainful employment opportunities for them. Therefore, the study was conducted by formulating the objectives as (i) what the profile characteristics of the rural male youths in Dhemaji district are? (ii) what types of livelihood activities do they follow?; (iii) what are the perceived reasons for pursuing those livelihood activities?; and (iv) what sort of problems they are facing in carrying out the livelihood activities?

\section{MATERIALS AND METHODS}

The study was carried out in Dhemaji district of Assam. The target population was restricted to rural male youths involving actively in livelihood activities between the ages of 18 to 35 years. Multistage sampling technique was used for selecting the respondents. There were total five development blocks in the district. All the blocks were affected by the flood. In the first stage, two blocks were selected randomly. At the second stage, from each selected block, five flood affected villages had been chosen randomly. Thus, the total numbers of selected villages were ten. These were 2 No. Barphuloni Gaon, Mesokachari Gaon, Betonipam, Laloong Gaon, Sarupam Hajong Gaon, Balijan, Nahoroni Borjan, Goroimari Bahoiting Gaon, and Chirpani Ahom Gaon.

Finally, from each selected village, 20 numbers of rural male youths had been selected through random sampling. Thus, 200 respondents were finally selected for the study. In the study, both structured and semi- 
structured questions were asked during the investigation. Total six variables were considered to describe the background characteristics of the respondents. These were age, educational level, the size of family, caste, operational land holding and average monthly income.

In this study, age was determined by the chronological age of the respondent at the time of the interview; education was measured by the formal education that has been received by the interviewee at the date of interview. The size of the family referred to the number of family members of the respondents. The caste referred as the social status or position of an individual that is fixed by birth. The operational land holding applied to the total land possessed by the respondent. Initially, annual income from all the sources of a respondent's family was calculated out in rupees and then, annual income was divided by 12 to obtain the average monthly income of the respondent.

For documenting the livelihood activities, the procedure of Parvin (2005) and Oladeji (2007) were followed with slight modification. The perceived reasons for practising the livelihood activities were also first documented and then analysed. Here, multiple responses of the respondents were worked out since explaining the reasons helps the policy makers, development workers, and others to implement the livelihood related scheme in the areas. Though all the livelihood activities followed by the respondents were reported in the paper, however, the activities which were pursued by five percent or more respondents were considered for further analysis of reasons. Respondents were also asked to mention the problems they are facing with existing livelihood activities. For each respondent, activities wise perceived problems were collected with the help of open-ended question. After collection of the problems, a similar type of issues was compiled and held under one common problem statement sub category. The total number of respondents under each category was obtained to determine frequency and percentages. Initially; all the common problems (38 nos.) were sorted out by this process. However, problems which were reported by more than $50.00 \%$ respondents were considered for further discussion in this paper. Mean and standard deviations were analysed for ratio level profile variables. Frequency and percentages were worked out for nominal and ordinal level variables. For existing livelihood activities followed by the respondents, reasons for pursuing the activities by the respondents, and perceived problems in pursuing the activities, frequency and percentages were calculated for analysis.

\section{RESULTS AND DISCUSSION}

Socioeconomic characteristics of respondents: Table 1 indicates that the mean age of the respondents was 28.83 years $(\mathrm{SD}=4.89)$. Kimaro et al. $(2015)$ argued that youth between the ages of 30-35 years are more grown up and considered agriculture as the most important income generating activity. The Table 1 shows that over sixty per cent of those surveyed had high school to the higher secondary level of education. The findings were contradictory to the Socio-Economic and Caste Census (2011) cited in Tewari (2015) reported that only $15.00 \%$ rural Indians including rural youths have an education from high school to higher secondary level. The Table 1 shows that the average size of the family of the respondents was five numbers $(\mathrm{SD}=$ 1.79). The finding was similar with rural Indian which was 4.93 (Socio Economic and Caste Census, 2011 cited in Tewari,2015) .Thakur and Barman (2014) also reported the mean family size of rural household in Assam as 4.62. The average land holding of the respondents was found as 1.67 ha $(\mathrm{SD}=1.47)$. The result was higher than the state average of 1.1 ha ('Economic Survey, Assam, 2014-15',n.d.). However, Das (2012) and Borah (2014) reported higher average land holding size of Dhemaji district than the state. Total $37.00 \%$ respondents belonged to the scheduled tribe category, followed by scheduled caste $(30 \%)$ as shown in Table 1. The Table 1 further indicates that the mean monthly income of the respondent's family was

Table 1. Socioeconomic characteristics of the respondents. $n=200$

\begin{tabular}{|c|c|c|c|c|c|}
\hline S. $\mathbf{N}$. & Characteristics & Frequency & Percentage & Mean & S.D. \\
\hline 1. & Age (Years) & & & 28.83 & 4.89 \\
\hline \multirow[t]{6}{*}{2.} & Educational level & & & & \\
\hline & Up to primary school & 13 & 6.50 & - & - \\
\hline & Up to Middle school & 42 & 21.00 & & \\
\hline & Up to high school & 67 & 33.50 & & \\
\hline & Up to Higher Secondary & 55 & 27.50 & & \\
\hline & Graduate and above & 18 & 9.00 & & \\
\hline 3. & Family members (Nos.) & & & 5.00 & 1.79 \\
\hline \multirow[t]{5}{*}{4.} & Caste & & & & \\
\hline & General & 18 & 9.00 & & \\
\hline & O.B.C./M.O.B.C. & 48 & 24.00 & & \\
\hline & Scheduled Caste & 60 & 30.00 & & \\
\hline & Scheduled Tribes & 74 & 37.00 & & \\
\hline 5. & Operational land holding (ha.) & & & 1.67 & 1.47 \\
\hline 6. & Average monthly income (Rs.) & & & $5,372.63$ & $1,588.97$ \\
\hline
\end{tabular}


Table 2. Existing primary livelihood activities followed by the respondents $n=200$.

\begin{tabular}{llll}
\hline S. N. & Different livelihood option followed & Frequency & Percentage \\
\hline 1. & Sali rice cultivation & 51 & 25.50 \\
2. & Vegetable cultivation & 23 & 11.50 \\
3. & Sali rice cultivation and Dairy (traditional) & 18 & 9.00 \\
4. & Dairy (traditional) & 14 & 7.00 \\
5. & Piggery (traditional) & 13 & 6.50 \\
6. & Goatery (traditional) & 12 & 6.00 \\
7. & Poultry (backyard) & 10 & 5.00 \\
8. & Fishery (traditional) & 10 & 5.00 \\
9. & Weaving & 10 & 5.00 \\
10. & Business & 9 & 4.50 \\
11. & Job in govt./private sector & 7 & 3.50 \\
12. & Agriculture and Business & 6 & 3.00 \\
13. & Beetle vine and arecanut & 5 & 2.50 \\
14. & Sericulture & 5 & 2.50 \\
15. & Piggery and Poultry (traditional) & 4 & 2.00 \\
16. & Sali rice cultivation and Daily wage earner (unskilled labour) & 2 & 1.00 \\
17. & Carpentry & 1 & 0.50 \\
\hline
\end{tabular}

Table 3. Perceived reason for practicing sali rice and vegetable cultivations as primary livelihood activities

\begin{tabular}{|c|c|c|c|}
\hline Livelihood activity & Perceived reason & Frequency * & Percentage \\
\hline \multirow{8}{*}{$\begin{array}{l}\text { Sali rice cultivation } \\
\left(\mathrm{n}_{1}=51\right)\end{array}$} & a) Land suitability & 51 & 100.00 \\
\hline & b) Ability to meet the food grain of the family & 49 & 96.07 \\
\hline & c) Suitability to provide income for the family & 47 & 92.15 \\
\hline & d) Continuity of fore father's practices & 45 & 88.23 \\
\hline & e) Social feasibility and acceptability & 43 & 84.31 \\
\hline & f) Ability to provide direct employment & 40 & 78.43 \\
\hline & g) Suitability to utilise local resources & 32 & 62.74 \\
\hline & h) Availability of fodder to feed livestock & 29 & 56.83 \\
\hline Vegetable cultivation & Continuity in year round production and good economic return & 22 & 95.65 \\
\hline \multirow[t]{9}{*}{$\left(\mathrm{n}_{2}=23\right)$} & Ability to meet family requirement & 21 & 91.30 \\
\hline & Availability of input & 20 & 86.95 \\
\hline & Productivity higher & 20 & 86.95 \\
\hline & Viability with other components / enterprises, higher & 19 & 82.60 \\
\hline & Availability of labour within the family & 16 & 69.56 \\
\hline & Less investment & 14 & 60.86 \\
\hline & Less risky & 10 & 43.47 \\
\hline & Availability of local market & 10 & 43.47 \\
\hline & Transportability easier to nearby area/ market & 9 & 39.13 \\
\hline
\end{tabular}

* Multiple responses

Rs.5,372.63 ( $\mathrm{SD}=1,588.97)$. Borah (2014) also indicated low income of farmers' of Dhemaji district.

Existing primary livelihood activities followed by rural youths: The study identified that respondents are pursuing 17 types of livelihood activities (Table 2). Over one-fourth of those surveyed reported that they are practising sali rice production. In a rice-centric district, the data indicates less involvement in paddy cultivation. It could be reasoned out that there is a significant effect of sand deposition and other adverse effects of periodic floods on fertile agricultural land, so people can not depend on paddy cultivation. 'Economy of Dhemaji District', (n.d.) also support the finding by reporting that a significant number of floodaffected people had shifted from rice to other sectors. About $11.50 \%$ practiced kharif and rabi vegetables as their main source of livelihood. For small land holders, vegetable cultivation is a good source of income. 'Economy of Dhemaji District'(n.d.) mentioned that farmers of Dhemaji had started testing to horticulture as an alternative under sand deposition. About nine per cent of the respondents was involved in "sali rice cultivation and dairy" followed by seven per cent was engaged in "dairy". Umunnakwe and Olajide-Adedamola (2015) also reported that rural youth are also involved in milk production for subsistence. There is always a demand for fresh whole milk in Assam due to deficit production. ('Economic Survey, Assam, 2014-15', n.d.). The scarcity of milk might influence the respondents for choosing dairy for livelihood.

Very few participants responded that they involve in other activities such as piggery $(6.5 \%)$, goatery $(6 \%)$, poultry $(5 \%)$, fishery $(5 \%)$, weaving $(5 \%)$, and business $(4.5 \%)$ (Table 2$)$. The Table 2 indicates that most respondent involved in crop production for livelihood in the sand affected district. The findings are supported by Oladeji (2007) who stated that in land degraded areas crop cultivation is the dominant practices. With- 
Table 4. Perceived reason for practicing sali rice cultivation and dairy as a primary livelihood activity

\begin{tabular}{llll}
\hline Livelihood activity & Perceived reason & Frequency * & Percentage \\
\hline Sali rice cultivation & a) Potentiality to provide additional income & 16 & 88.88 \\
and Dairy $\left(\mathrm{n}_{3}=18\right)$ & c) Insufficiency of land to extend agriculture alone to earn adequate & 14 & 77.77 \\
& family income & 12 & 66.66 \\
& d) Availability of space in the homestead for dairy cattle rearing & 14 & 100.00 \\
Dairy & Regularity in earning cash income through the sale of milk & 14 & 100.00 \\
$\left(\mathrm{n}_{4}=14\right)$ & Fulfilment of milk requirement of the family & 13 & 92.85 \\
& Growing demand for milk and milk product round the year & 11 & 78.57 \\
& Requirement of less time span and ease in management & 11 & 78.57 \\
& Flexibility in working time for dairy management & 10 & 71.42 \\
& Availability of space for rearing & 10 & 71.42 \\
& Knowledge of traditional practice helpful in learning scientific dairy & 10 \\
& management & 9 & 64.28 \\
& Less dependence on weather factors & 8 & 57.14 \\
& Less dependence on hiring labour & 7 & 50.00 \\
\hline
\end{tabular}

* Multiple responses

Table 5. Perceived reasons for practicing piggery as a primary livelihood activity

\begin{tabular}{llll}
\hline Livelihood activity & Perceived reason & Frequency * & Percentage \\
\hline Piggery & Less dependence on weather factors & 13 & 100.00 \\
$\left(\mathrm{n}_{5}=13\right)$ & High popularity amongst consumers and growing market demand of & 13 & 100.00 \\
& pork & 12 & 92.30 \\
& Availability of local market & 11 & 84.61 \\
& Ability to meet family requirement of pork & 10 & 76.92 \\
& Availability of space & 8 & 61.53 \\
\hline
\end{tabular}

* Multiple responses

Table 6. Perceived reason for practicing goatery as a primary livelihood activity

\begin{tabular}{llll}
\hline Livelihood activity & Perceived reason & Frequency * & Percentage \\
\hline Goatery & Potentiality for earning good returns & 12 & 100 \\
$\left(\mathrm{n}_{6}=12\right)$ & Good market demand of chevon & 11 & 91.66 \\
& Good market price of chevon & 11 & 91.66 \\
& Low risk & 10 & 83.33 \\
& Low investment & 10 & 83.33 \\
& Social feasibility and acceptability & 10 & 83.33 \\
& Requirement of less care and management & 9 & 75.00 \\
& Availability of space in the homestead & 7 & 58.33 \\
\hline
\end{tabular}

\footnotetext{
* Multiple responses
}

in the area of investigation, some studies claimed that rural people pursue various types of activities for livelihood. Oladeji (2007) identified 12 agricultural income generating activities and 18 non-agricultural income generating activities in Nigeria. Sheheli (2012) argued that in Bangladesh rural women even involved in 11 types of livelihood activities. Simmilar type of findings were also reported by Ovwigho (2014) andUmunnakwe et al., (2014); Bennell (2010) opined that rural youths involve in different activities for livelihood. The general picture emerging from the analysis is that rural male youths were practising diversified livelihood activities in the surveyed area.

Reasons for selection of livelihood activities as perceived by the rural youth: Over one-fourth of those surveyed $\left(\mathrm{n}_{1}=51\right)$ stated that they are practising sali rice production (Table 3 ). The present study found that $88.23 \%$ respondents $\left(\mathrm{n}_{1}=51\right)$ have been just continuing sali paddy cultivation as it is their traditional practice. This section of youths might be vulnerable to withdraw from rice cultivation once they get an opportunity. Table 3 shows that $11.50 \%$ respondents $\left(n_{2}=23\right)$ cultivated vegetables as livelihood activities. Out of these $\left(\mathrm{n}_{2}=23\right)$, the majority of the respondents $(95.65 \%)$ perceived that continuity in year round production and income was the reason for vegetable cultivation.

From Table 4 shows that $88.88 \%$ respondents $\left(n_{3}=18\right)$ perceived that "sali rice cultivation along with dairy" provide additional income to them. The respondents practiced dairy traditionally (open grazing system) with indigenous cattle breed. In case of "dairy", all the respondents $\left(\mathrm{n}_{4}=14\right)$ perceived that regularity in income through the sale of milk was an important reason for choosing dairy as a primary livelihood activity. Year round demand for milk and milk product was 
Table 7. Perceived reasons for practicing backyard poultry as a primary livelihood activity

\begin{tabular}{llll}
\hline Livelihood activity & Perceived reason & Frequency & Percentage \\
\hline Poultry (Backyard) & a) High demand in the local market & 10 & 100.00 \\
$\left(\mathrm{n}_{7}=10\right)$ & b) High market price for egg and meat & 10 & 100.00 \\
& c) Ability to meet egg and meat requirement the family & 9 & 90.00 \\
& d) Ease in poultry management & 8 & 80.00 \\
& e) Ability to achieve higher production in shorter time & 7 & 70.00 \\
& f) Potentiality for providing income to the family & 6 & 60.00 \\
\hline
\end{tabular}

* Multiple responses

Table 8. Perceived reason for practicing weaving as a primary livelihood activity

\begin{tabular}{llll}
\hline Livelihood activity & \multicolumn{1}{c}{ Perceived reason } & Frequency * & Percentage \\
\hline Weaving & a) Availability of traditional knowledge and skill & 10 & 100.00 \\
$\left(\mathrm{n}_{8}=10\right)$ & b) High demand of handloom products in the market & 10 & 100.00 \\
& c) Easy availability of raw material & 9 & 90.00 \\
& d) Better income from lesser investment & 8 & 80.00 \\
& e) Ability to meet family requirement & 7 & 70.00 \\
& f) Possibility to sell products directly to Handloom Department \\
& from time to time & 6 & 60.00 \\
\hline
\end{tabular}

* Multiple responses

also another perceived reason for $92.85 \%$ respondents $\left(\mathrm{n}_{4}=14\right)$. In 2013-14, the deficit production of milk in Assam was 1566 million litres ('Economic Survey, Assam, 2014-15',n.d.). It indicates that dairy is a potential economic activity if followed scientifically with the improved cross breed.

Table 5 shows that 13 respondents $\left(n_{5}=13\right)$ practiced piggery as primary a livelihood activity because it less depends on the weather. In flood affected areas of Dhemaji, piggery was one of the easy and quick sources of income (Assam State Rural Livelihoods Mission Society, 2011-12). Some other reasons of "piggery" as perceived by respondents were increased popularity of pork amongst consumers and growing market demand. Pegu (2014) argued that piggery sector has become the main point of attention in the district. The government data showed the deficit production of meat in Assam ('Economic Survey, Assam, 2014-15', n.d.). So, to meet the deficit, piggery is a good option. However, they will earn more with the improved crossbreed since around $90.00 \%$ of the pig population of the district was indigenous pigs with less potentiality for growth and production (ICAR-ATARI, Umium, 2016).

Table 6 indicates that, in case of gottery $\left(\mathrm{n}_{6}=12\right)$, potentiality for earning sufficient income was the main reason for pursuing the enterprise. Market demand for mutton and the profitable market price were another reason felt by the respondents. Goat can quickly adapt the adverse environment and excellent meat quality as stated by Sarkar(n.d.). The market price of mutton is in the range of Rs. 350- 400/kg in Assam (Sourceprimary data). Therefore, goatery is another good choice for livelihood activities in the district for rural youths.

From Table 7 it is found that respondent $\left(n_{7}=10\right)$ who had followed backyard poultry as a primary livelihood activity perceived that high demand in the local market, and high market price of eggs and chicken meat were some reasons of "poultry" as a source of livelihood activity. In Assam, there is a shortage of meat and egg production. 'Economic Survey, Assam ,201415', n.d). Islam et al. (2015) revealed that the benefitcost ratio of improved dual type chicken like Vanaraja is better than local chicken under backyard system of rearing in Assam. So it will be an alternative intervention in the case of backyard poultry rearing.

Some perceived reasons for practising "weaving" by the respondents $\left(\mathrm{n}_{8}=10\right)$ where possession of traditional knowledge, skill and high market demand of handloom product (Table 8). Dhemaji district occupies a unique place in the production of three different kinds of silks - Pat (Bombyx mori), Muga (Antheraea assamensis) and Eri(Samia cynthia ricini). It has a very high demand in the national and international markets ('Economy of Dhemaji District', n.d.). Since the district is traditionally rich in sericulture and weaving, so this sector has a tremendous scope as livelihood activities.

High market demand was the main reasons for selection of "fishery"(Table 9) as felt by those who responded $\left(n_{9}=10\right)$. The people of Assam prefer fish, but the state is not self-sufficient in fish production. In 201314 , fish imported from outside the state was 12,830 MT ('Economic Survey, Assam, 2014-15', n.d.). National Fisheries Development Board , (2015) also supported the findings by stating that fishery is one of the most promising areas for alleviating poverty and providing livelihoods in Assam. So, it might be a useful intervention for livelihood approach.

Problems associated with selected livelihood activities as perceived by the rural youth: Table 10 indicates that regular flood or flash flood was viewed as a major challenge by all who opted 'sali rice cultivation', 
Table 9. Perceived reasons for practicing fishery as a primary livelihood activity

\begin{tabular}{llll}
\hline Livelihood activity & Perceived reason & Frequency * & Percentage \\
\hline Fishery & a) Higher market demand & 9 & 90.00 \\
$\left(\mathrm{n}_{9}=10\right)$ & b) Ability to meet family requirement of fish & 8 & 80.00 \\
& c) Requirement of lesser care or management & 7 & 70.00 \\
& d) Lower investment & 7 & 70.00 \\
\hline
\end{tabular}

* Multiple responses

Table 10. Major problems faced by the respondents for practicing livelihood activities

\begin{tabular}{|c|c|c|}
\hline S. $\mathbf{N}$. & Problems* & Livelihood activities $* *$ \\
\hline 1. & Regular occurrence of flood or flash flood & $\begin{array}{l}\text { Sali rice cultivation }(100 \%) \text {, vegetable cultivations }(100 \%) \text { and } \\
\text { fishery }(100 \%) \text {. }\end{array}$ \\
\hline 2. & $\begin{array}{l}\text { Unsuitability of the land due to flood induced } \\
\text { sand and silt deposition in crop fields }\end{array}$ & Sali rice cultivation (100\%) and vegetable cultivations $(100 \%)$. \\
\hline 3. & Lack of irrigation facilities & Sali rice cultivation $(100 \%)$, vegetable cultivations $(100 \%)$. \\
\hline 4. & Erratic rainfall in cropping season & Sali rice cultivation $(100 \%)$ and vegetable cultivations $(100 \%)$. \\
\hline 5. & $\begin{array}{l}\text { Shortage of labour during peak period of crop- } \\
\text { ping season }\end{array}$ & Sali rice cultivation $(100 \%)$ and vegetable cultivations $(100 \%)$. \\
\hline 6. & Lack of remunerative prices for farm produce & Sali rice cultivation $(98.03 \%)$ and vegetable cultivations $(100 \%)$. \\
\hline 7. & Lack of market facility & Vegetable cultivations $(91.3 \%)$ and dairy $(78.57 \%)$. \\
\hline 8. & Price fluctuation of crop products & "Sali rice cultivation +Dairy" $(88.88 \%)$. \\
\hline 9. & High price of livestock breed & Dairy $(100 \%)$, piggery $(100 \%)$ and poultry $(100 \%)$. \\
\hline 10. & Lack of capital for investment & Dairy $(92.85 \%)$ and piggery $(76.92 \%)$. \\
\hline 11. & Lack of easy finance & Dairy $(57.14 \%)$ and piggery $(76.92 \%)$. \\
\hline 12. & Occurrence of diseases of livestock & $\begin{array}{l}\text { Dairy }(85.71 \%) \text {, piggery }(69.23 \%) \text {, poultry }(100 \%) \text { and goatery } \\
(66.66 \%) \text {. }\end{array}$ \\
\hline 13. & Lack of veterinary facilities & Dairy $(83.33 \%)$, piggery $(61.53 \%)$. and poultry $(60.01 \%)$ \\
\hline 14. & Shortage of grazing areas for cattle & Dairy $(68.75 \%)$ \\
\hline 15. & Non availability of quality fingerlings & Fishery $(80 \%)$ \\
\hline 16. & Non availability of quality fish feed & Fishery $(50 \%)$ \\
\hline
\end{tabular}

* Multiple responses ** In parentheses, percentage of respondents who responded

'vegetable cultivations' and 'fishery'. Unsuitability of farmland because of sand and silt deposition was also a problem for the respondents choosing 'sali rice' and 'vegetable' cultivation. These findings are consistent with ICAR-ATARI-Umium (2016) that more than $20.00 \%$ of the area of Dhemaji district are sand deposited at various depths causing major problems for crop production. Das (2012) also reported that the productivity of paddy was decreasing due to flood-induced sand in Dhamaji. It might be a major problem for paddy cultivators in near future when the productivity of paddy will declining, or land will not be suitable for cultivation. In the case of the fishery, Bordoloi and Muzaddadi (2015) reported that very tall, broad and vigorous dykes were constructed by people to protect the pond from floodwater in Dhemaji. This type of extra protection increased cost of production and thereby reduces the profits .

Unavailability of irrigation facilities was another issue for crop cultivations. In Dhemaji district, the net irrigated area was only11.40\% (ICAR-ATARI, Umium, 2016). In sand and silt deposited areas, it is problematic to cultivate crop without adequate irrigation. Uneven rainfall was also a problem for the cultivators. This finding is in line with Directorate of Economics and Statistics, GoA (2014) that monthly rainfall pattern of
Dhemaji district was erratic.Under erratic rainfall, it is hard to grow crops successfully under rainfed condition. All the sali rice and vegetable cultivators felt the issue of shortage of labour during peak crop season. Chetia(2014) argued that due to the flood the vast scale of young people from Dhemaji district migrates to other states in search of livelihood. It might be a reason for the scarcity of labour.

Most respondents felt that they do not get profitable prices from crop products. Insufficient market facility and price fluctuation were also a hardship for the youths (Table 10). Youths if not getting the moneymaking prices for their products, in future, they might search alternative option. The 'Economy of Dhemaji District' (n.d.) also supported the findings that the district lacks good communication system and marketing facilities. Price fluctuation of farm products such as sali rice; vegetables were also major issues as felt by those who responded (Table 10). Yadav (2011-12) argued that farmers of Assam do not get the right price of product. She also reported about lack of infrastructure for marketing. It is necessary for Government to addresses those issues like development of marketing infrastructure, establishment and expansion of market network and identification of effective channels so that farmers will get the profitable prices by utilising the 
benefits of existing marketing opportunities.

All the respondents under livestock perceived high price of the improved cross breed as an issue (Table 10). It might be due to lack of improved cross breed production unit. The State Animal Husbandry and Veterinary Department, Assam also echoed the same problem in the case of cattle and pig ('Economic Survey, Assam, 2014-15',n.d.). In the event of chicks, cost of day old broiler cob was high. The price was Rs.47.00 ex Guwahati as on March19,2017(Hatchery Association of Assam [Advertisement] 2017, March 19) which reflected the high price. If the cost of chicks is high, more capital would be needed to run such enterprise profitably .

The dearth of capital for investment in livelihood was an obstacle for dairy and piggery sector. Deka et al. (2007) argued that lack of working capital be a recurring constraint especially during the flood and postflood periods in the district. This type of problem hinders the maintenance of livelihood activities. . Most of the respondents adopting dairy and piggery reported that getting finance for livelihood is not easy. Rashtriya Gramin Vikas Nidhi (2015) maintained that getting a loan from a bank is difficult for farmers in the district. In severely flood affected areas, people had been losing their assets regularly. So they needed capital from external sources for maintenance and development of such assets. The existing situation reveals that most of the respondents were yet to be bankable.

Over half of the respondents felt that diseases of livestock such as cattle, pig, goat and poultry birds and inadequacy of veterinary services are a major problem for them. Sarkar (n.d.) affirmed that in Assam recurrence of flood causes a high incidence of diseases among livestock. Deka et al. ( 2007) also argued that in Dhemaji district veterinary service facilities are destitute. 'Economy of Dhemaji District'(,n.d.) also supported that the rural people are not benefiting from the existing veterinary services because of nonavailability of veterinary personnel and medicines. Therefore, it is necessary to strengthen the veterinary department with all necessary elements such as human resources, drugs and equipment. Special boat service should be arranged to serve the affected livestock during the flood.

The scarcity of grazing land was an obstacle for the dairy sector (Table 10). The grazing lands were occupied or damaged rapidly in Dhemaji. ('Live Better With the Flood- ...',n.d. ). Doley(2015) supported the findings who claimed the loss of grazing land in Dhemaji district due to flood. Singh and Ram Niwas (2012) and Sarkar ( n.d. ) also emphasised that disappearance of a vast number of grazing reserves adversely affect the livestock sector. Traditionally dairy is practising under open grazing system so rapid shrinkage of grazing land is a threat to the dairy sector. With the increasing pressure of population and sand deposi- tion, there is more chance for decreasing areas of grazing land in the district. So it is better to adopt scientific dairy practices by the rural youths.

More than three fourth of the rural youths who were interviewed under fishery felt that dearth of quality fingerlings is a major problem for them. The fishery is a good choice for the rural youths provided the highquality fish seed be made available to them. Das ( 2000 ) also emphasised the importance of production of quality fish seed for Assam. Rashtriya Krishi Vikash Yojana,,Assam (2014-15) claimed that Assam is yet to produce quality fingerling at the right time uniformly throughout the State. Therefore, the establishment of quality fish breeding plant is necessary to provide quality fingerlings to capture the potential fish market by the interested youths. Non-availability of quality fish feed was another problem as reported by half of the respondents practising fishery (Table 10). According to NABARD (as cited in 'Economic Survey, Assam, 2014-15',n.d.) establishment of fish meal plants in Assam is essential for the development of the fishery sector.

\section{Conclusion}

The evidence from this study implies that most respondents had minimum high school level education, had the poor economic condition and had small and marginal landholdings. The findings of this study indicate that rural male youths follow various types of livelihood activities of which majority are agricultural based. About one-third of the youths opted livestock and fishery for subsistence. The rural youths have their choices for pursuing of livelihood activities. In the study area, most respondents cited the reasons for selecting portfolios such as high market demand scope for income generation, availability of space for establishing enterprise and adaptability to the local condition. This study has obtained satisfactory findings showing that though youths of the study area have been practising potential portfolios and they are facing challenges to run these activities. There were some major problems such as extreme flood, sand affected farmland, obtaining the low price of products, poor market facilities, and complexity in getting credit. More than half of the youths practising livestock and fishery in the survey area reported problems such as nonavailability of improved livestock breed, poor veterinary services, quality fingerlings and fish feed. Most of the rural youths of the survey area preferred farming as livelihood considering the potentialities in the district. In general, these findings would seem to suggest that the issues encountered by the youths might be resolved urgently. Otherwise shortly, they may lose interest in farming and may shift to other sectors. An implication of the survey is that the findings will help policy makers, extension organisations and other institutes for 
improving the livelihood of the male rural youth of the district. The findings of the study will provide a basis for a new way to do livelihood development programme in the district.

\section{REFERENCES}

Alemu, Z.G. (2012). 'Livelihood strategies in rural South Africa: implications for poverty reduction'. Selected paper prepared for presentation at the International Association of Agricultural Economists (IAAE) Triennial Conference, Foz do Iguacu, Brazil. Retrieved December $18, \quad 2015$ from http://ageconsearch.umn.edu/ bitstream/125411/2/ZG\%20Alemu\%20IAAE.pdf.

Assam State Rural Livelihoods Mission Society (2011). 'A study on contributing and limiting factors relating to pig rearing as a source of income in Assam (Rep.)', p. 5. Retrieved April 8, 2017 from www.asrlms.in/ Downloads/study_report.pdf

Bakshi, P. (2013). Decreasing land holdings biggest challenge for Indian agriculture: NABARD. An interview published in The Economics Times on Aug 24, 2013 given to Dhandeo, H.D. (2013). Retrieved July 15, 2015 from $\mathrm{http}: / /$ articles.economictimes.indiatimes.com/201308-24/news/41444004_1_indian-agriculture-one-crorefarmers-farmers-capacity.

Bennell, P. (2010). 'Investing in the future, creating opportunities for young rural people'. p. 5. Retrieved July 18, 2015 from http://www.ifad.org/events/gc/34/panels/ invest_future.pdf

Borah, D. (2014). An analysis of livelihood diversification among the farmers of sand and silt deposited areas of Dhemaji district of Assam. M.Sc thesis (Unpublished) Assam Agricultural University, Jorhat, India

Bordoloi, R. and Muzzaddadi, A.U.(2015). Indigenous technical knowledge associated with disaster management and fisheries related activities in the highest flood affected district (Dhemaji) of Assam, India. Indian J Tradit Know . 14(3) :407-415. Retrieved April 8, 2017 from http://nopr.niscair.res.in/bitstream/123456789/32104/1/ IJTK\%2014(3)\%20407-415.pdf

Census of India (2011) $)^{\mathrm{a}}$. C-13 Single year age returns by residence and sex. Retrieved July 15, 2015 from www.censusindia.gov.in/2011 census/C-series/c-13/ DDW-0000C-13.xls

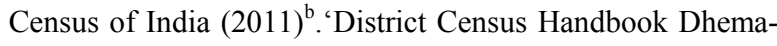
ji'. Series-19, Part XII-B, Directorate of Census Operations, Assam. Retrieved July 15, 2015 from www.censusindia.gov.in/2011census/ dchb/1809 PART B DCHB DHEMAJI.pdf

Chetia, J. (2014). Migration and employment in India: a study in Dhemaji district of Assam. Int J Current Res. 6 (1): 4781-4783. November 14, 2016 from http:// www.journalcra.com/sites/default/files/4720.pdf

Das, S.K. (2000). Fish seeds: quality vs quantity -a practical approach to quality fish seed production. In S.K.Das (ed.) Proceedings of the first state-level workshop on current status and future of the fish seed production industry in the State of Assam. April 8-9, 1999. Special Publication 3, College of Fisheries, Assam Agricultural University, Raha, Nagaon, Assam, India. pp. 1-4. Retrieved November 15, 2016 from http:// assamagribusiness.nic.in/New/ FishSeedProductionIndustry.pdf
Das, K.(2012). Farm productivity loss due to flood-induced sand deposition: a study in Dhemaji, India. OKD Institute of Social Change and Development, Guwahati, India and South Asian Network for Development and Environmental Economics, Kathmandu, Nepal. Retrieved September 8, 2016 from http://www.sandeeonline.org/ uploads/documentspublication/990_PUB_Working Paper_73_Kalyan_Das.pdf

Deka, $\bar{R}$. , Thorpe, W., Lapar, M.L., and Kumar, A. (2007). 'Dhemaji's pig sub-sector: current status, constraints and opportunities'. ILRI, Nairobi (Kenya). Retrieved April 8, 2017, from http://hdl.handle.net/10568/1778

Directorate of Economics and Statistics, Government of Assam (2014). 'Statistical Hand Book, Assam 2013', $45^{\text {th }}$ series. pp. 66-69. Retrieved Oct 11, 2016 from http://www.ecostatassam.nic.in/reports/SHB2013.pdf

Doley, L. C. (2015). Flood that threats the biodiversity of dhemaji: impacts and responses. Int. J. Entrepreneurship \& Business Environment Perspectives, 4(2), 1732-1737. Retrieved April 18, 2017, from pezzottaitejournals.net/ pezzottaite/images/ISSUES/V4N2/IJEBEPV4N217.pdf.

Economic Survey, Assam, 2014-15 (n.d.). 'Economic Survey, Assam, 2014-15'. Retrieved September 10, 2016 from http://ecostatassam.nic.in/reports/economic_survey 2014-15.pdf

Economy of Dhemaji District (n.d.).2016 Retrieved August 18, 2016 from http://dhemaji.nic.in/economy.htm

Government of India (2010). 'Migration in India- 2007-08' . National Sample Survey Office, Ministry of Statistics and Programme Implementation, New Delhi. Retrieved November 14, 2016 from http://mospi.nic.in/sites/ default/files/publication_reports/533_final.pdf

Hatchery Association of Assam [Advertisement]. (2017, March 19). Dainik Janambhumi, an Assamese daily news paper p. 7

Introduction (n.d.). Retrieved November, 8, 2015 from http://shodh.inflibnet.ac.in/ bitstream/123456789/ 192/2/02_ntroduction.pdf

ICAR - Agricultural Technology Application Research Institute (ATARI), Umium (2016). 'Dhemaji district Inventory of Agriculture- 2015' The Director, ICAR - Agricultural Technology Application Research Institute, Umium, Meghalaya- Retrieved April 11, 2017 from http:// www.icarzcu3.gov.in/Dist_Agri_Inventory/Dhemaji.pdf

IFAD(2017). 'Rural Poverty Report 2001: The Challenge of Ending Rural Poverty'.As cited in Umunnakwe,V.C., Pyasi, V.K. and Pande, A.K. (2014).Factors influencing involvement in agricultural livelihood activities among rural youth in Jabalpur district of Madhya Pradesh, India. Int. J. Agric. Pol. Res. 2 (8): 288-295. Retrieved September 20, 2015 from http://journalissues.org/wpcontent/uploads/2014/08/Umunnakwe-et-al.pdf

Islam R., Nath P., Bharali A. and Borah, R.(2015). Analysis of benefit-cost(B:C)ratio of Vanaraja and local chicken of Assam under backyard system of rearing. J. Res. Agric. Anim. Sci. 3(7):7-10. Retrieved April 11, 2017, from http://www.questjournals.org/jraas/papers/vol3issue 7/B370710.pdf

Jha, S. (2014). 'Jobs fail to catch up with India's growing youth population'. Retrieved July 15, 2015 from http:// www.business-standard.com/article/economy-policy/ jobs-fail-to-catch-up-with-india-s-growing-youthpopulation-114070300112_1.html 
Joshi, P.K., Tewari, L. and Birthal, P.S. (2006). Diversification and its impact on smallholders: evidence from a study on vegetable production. Agril. Economics Res. Rev. 19(2): 219-236.

Kimaro, P.J., Towo, N.N. and Moshi, B.H. (2015). Determinants of rural youth's participation in agricultural activities: the case of Kahe East Ward in Moshi rural district, Tanzania. Int. J. Economics, Commerce and Management. 3(2):1-47. Retrieved April 11, 2017 from http:// ijecm.co.uk/wp-content/uploads/2015/02/3235.pdf

Krantz, L. (2001). 'The sustainable livelihood approaches to poverty reduction- an introduction'. Swedish International Development Cooperation Agency, Division for Policy and Socio-Economic Analysis. Retrieved July 5, 2015 from http://www.sida.se/contentassets/ bd474c210163447c9a7963d77c64148a/the-sustainablelivelihood-approach-to-poverty-reduction_2656.pdf

Live Better With the Flood - An Approach for Sustainable Livelihood Security in District Dhemaji, Assam- A Case Study' (n.d.). Retrieved April 18, 2017 from http:// www.afpro.org/naip/wp-content/uploads/ sites/4/2013/12/Case-Study-NAIPAFPRO.pdf

Livelihood-Rural Indian-Citizens: National Portal of India (2012). Retrieved April 11， 2017 from http:// www.archive.india.gov.in/citizen/graminbharat/ graminbharat.php?id=2

National Fisheries Development Board (2015). Sustainable livelihoods promotion through fish drying activity by SHGs at Community Resource Centres in Assam. Matsya Bharat. 7(2): 5-9.

National Sample Survey Organisation (2005). 'Situation assessment survey of farmers some aspects of farming'. NSS $59^{\text {th }}$ Round (January-December 2003), Report No. 496(59/33/3). National Sample Survey Organisation, Ministry of Statistics and Programme Implementation, Government of India. Retrieved November 14, 2015 from http://mospi.nic.in/Mospi_Newupload/496final.pdf

Oladeji, J.O. (2007). Effect of land degradation on income generating activities of farmers in Imo State, Nigeria. $J$. Econ. Rural Dev.16 (1): 93-106. Retrieved September 12,2013 from http://ageconsearch.umn.edu/ bitstream/147638/2/ Dr.\%20Oladeji.pdf

Ovwigho, B.O. (2014). Factors influencing involvement in nonfarm income generating activities among local farmers: the case of Ughelli South Local Government Area of Delta State, Nigeria. Sustainable Agric. Res. 3(1): 76-84. Retrieved November 14, 2015 from http:// dx.doi.org/10.5539/sar.v3n1p76

Parvin, G. A., Ahsan, S. M. R., and Chowdhury, M. R. (2004). Women empowerment performance of income generating activities supported by Rural Women Employment Creation Project (RWECP): a case study in Dumuria Thana, Bangladesh. J. Geo-Environment.4: 4762. Retrieved September 10, 2013 from http:// dept.ru.ac.bd/geography/Article_5.PDF

Pegu, B. J. (2014). Piggery entrepreneurship in Dhemaji district of Assam. M.Sc.thesis(Unpublished). Assam Agricultural University, Guwahati.

Planning Commission (2003). Report of the Force on "Identification of Districts for Wage and Selfemployment Programmes". Planning Commission, In Riders for NREGA: challenges of backward districts. $p$ 6. Retrieved September 10, 2015 from http://
nrega.nic.in/Planning_Commision.pdf

Rashtriya Krishi Vikash Yojana, Assam (2014-15). Status of Fishery Sector with special reference to implementation of RKVY schemes in the state of Assam. Rashtriya Krishi Vikash Yojana, Assam Department of Agriculture, Government of Assam. Retrieved November 18, 2016 from http://rkvyassam.in/?fish

Rashtriya Gramin Vikas Nidhi (2015). Scoping analysis on livelihood generation for recovery Under GOI-UNDP project on 'Enhancing Institutional \& Community Resilience to Disaster and Climate Change' Assam State Disaster Management Authority, Government of Assam. p 10. Retrieved November 18, 2016 from http:// asdma.gov.in/download/Scoping\%20Analysis\%20on\% 20Livelihood $\% 20$ Generation $\% 20$ for $\% 20$ Recovery.pdf

Sanghi, S. and Srija, A. (2014). 'Youth unemployment in India. Focus of the month'. Confederation of Indian Industries. Retrieved September 11, 2015 from http:// www.ies.gov.in/pdfs/sunita-sanghi-and-a-srija.pdf

Sarkar, A. B. (n.d.). 'Strategies for development of animal husbandry in Assam'. Retrieved November 10, 2016 from http://www.ncap.res.in/upload_files/workshop/ wsp $10 / \mathrm{html} /$ chapter $5 . h t m$

Sharma, A. and Bhaduri, A. (2009). The "Tipping Point" in Indian agriculture: understanding the withdrawal of the Indian rural youth. Asian J. of Agric. and Dev. 6(1): 8397. Retrieved July 21, 2015 from http:// ageconsearch.umn.edu/bitstream/199072/2/ AJAD 20096 1 5Sharma.pdf

Sheheli, S. (2012). Improving livelihood of rural women through income generating activities in Bangladesh. Ph.D. dissertation, Humboldt University, Berlin, Germany. p.85. Retrieved September 11, 2016 from http:// edoc.hu-berlin.de/dissertationen/sheheli-shonia-2012-0127/PDF/sheheli.pdf

Singh, D.P. and Ram Niwas ( 2012). Upliftment of Rajasthan through livestock farming. Raj. J. Extn. Edu. 20 : 27-31. Retrieved September 11, 2016 from http:// www.rseeudaipur.org/wp-content/ uploads/2013/02/084.pdf

Swaminathan, M.S. (2001). 'Shaping our Agricultural Future', The Hindu, Thursday, January 11, 2001. Retrieved September 30, 2015 from $\mathrm{http} / /$ www.thehindu.com/2001/01/11/stories/05112524.htm

Tewari, R. (2015). Socio Economic \& Caste Census 2011: A mobile in 2 of every 3 rural homes, a salaried job in 1 of 10. Retrieved April 09, 2017 from http:// indianexpress.com/article/india/india-others/socioeconomic-caste-census-2011-a-mobile-in-2-of-every-3rural-homes-a-salaried-job-in-1-of-10/

Thakur, A. and Barman, U. (2014). Factors influencing entrepreneurial behaviour of women self-help group members formed under Swarnajayanti Gram Swarozgar Yojna in Jorhat district of Assam. Int. J. Agril. Sci., 10(1):402-408

Umunnakwe,V.C., Pyasi, V.K. and Pande, A.K. (2014).Factors influencing involvement in agricultural livelihood activities among rural youth in Jabalpur district of Madhya Pradesh, India. Int. J. Agric. Pol. Res. 2 (8): 288-295. Retrieved September 20, 2015 from http:// journalissues.org/wp-content/uploads/2014/08/ Umunnakwe-et-al.pdf

Umunnakwe,V.C and F.O. Olajide-Adedamola, F.O. ( 2015) Socio-personal correlates of participation in livelihood 
Madhu Kakoty et al. / J. Appl. \& Nat. Sci. 10 (1): 111 - 121 (2018)

activities among rural youth in Jabalpur district of Madhya Pradesh, India. Int. J. Agril. Res. Innov. and Tech. 5 (1): 28-35 http://www.banglajol.info/index.php/ IJARIT/article/view/24584/16670

Vergas Lundius , R. and Lanly, G. (2007). Migration and rural employment. Paper prepared for the round table organised by the Policy Division during the Thirtieth Session of the Governing Council of IFAD: pp. 12-24. Retrieved September 20, 2015 from http:// www.ifad.org/events/gc/30/roundtable/migration/ proceedings.pdf

Waldie, K. (2004).'Youth and rural livelihoods'. LEISA Magazine 20(2) Retrieved September 20, 2015 from http://www.agriculturesnetwork.org/magazines/global/ new-generation-of-farmers/youth-and-rural-livelihoods
World Bank (2007). World Development report 2007: Development and the next generation. The World Bank, Washington D.C. Retrieved September 11, 2015 from http://documents.worldbank.org/curated/ en/556251468128407787/ pdf/359990WDR0complete.pdf

Yadav, H. (2011-12). Agricultural marketing system in Assam (Rep.). Jaipur, Rajasthan: National Institute of Agricultural Marketing. Retrieved April 9, 2017, from doi:https:/ccsniam.gov.in/ images/ pdfs/ Assam_Research_report.pdf Youth Participation 2013-1112 - United Nations. (n.d.). Retrieved April 11, 2017 from http://www.un.org/esa/socdev/documents/youth/ fact-sheets/youth-participation.pdf 